\title{
Article \\ Differing Responses to Cryphonectria parasitica at Two Indiana Locations
}

\author{
Shaneka S. Lawson ${ }^{1, *}$, Aziz Ebrahimi ${ }^{2}$ and James R. McKenna ${ }^{1}$ \\ 1 USDA Forest Service, Northern Research Station, Hardwood Tree Improvement and Regeneration \\ Center (HTIRC), Department of Forestry and Natural Resources, Purdue University, 715 West State Street, \\ West Lafayette, IN 47907, USA; mckennaj@gmail.com \\ 2 Department of Forestry and Natural Resources, Purdue University, HTIRC, 715 West State Street, \\ West Lafayette, IN 47907, USA; aebrahimi58@gmail.com \\ * Correspondence: shaneka.s.lawson@usda.gov; Tel.: +1-765-808-8188; Fax: +1-765-494-9461
}

Citation: Lawson, S.S.; Ebrahimi, A.; McKenna, J.R. Differing Responses to Cryphonectria parasitica at Two Indiana Locations. Forests 2021, 12, 794. https://doi.org/10.3390/f12060794

\section{Academic Editors:}

Kateryna Davydenko, Ari M. Hietala and Young-Seuk Park

Received: 14 April 2021

Accepted: 10 June 2021

Published: 16 June 2021

Publisher's Note: MDPI stays neutral with regard to jurisdictional claims in published maps and institutional affiliations.

Copyright: (c) 2021 by the authors. Licensee MDPI, Basel, Switzerland. This article is an open access article distributed under the terms and conditions of the Creative Commons Attribution (CC BY) license (https:// creativecommons.org/licenses/by/ $4.0 /)$.

\begin{abstract}
Chestnut blight, a disease that has spread rampantly among American (Castanea dentata (Marsh.) Borkh.) and European chestnut (C. sativa Mill.) trees, results from infection by the fungal pathogen Cryphonectria parasitica (Murrill) M.E. Barr (C. parasitica). This fungus was introduced in the early 1900s and has almost functionally eliminated chestnut trees from the North American landscape. In 2017, we collected chestnut blight samples from two sites (Site B, (Fulton Co., IN) and Site C (Marshall Co., IN)). At the Fulton County planting, Site B, cankers had formed, healed over, and the trees were healthy. However, at the second site in Marshall County, (Site C), cankers continued to propagate until all of the chestnut trees had died back to the ground. Research evidence worldwide has indicated that these visual clues likely result from the presence of a hypovirus. Upon closer inspection and the subsequent isolation and reproduction of spores, no hypovirus has been identified from either site. Here, we present a curious coincidence where one site has completely succumbed to the disease, while the other has been able to spring back to health.
\end{abstract}

Keywords: American chestnut; Castanea dentata; chestnut blight; Cryphonectria parasitica; Indiana

\section{Introduction}

Chestnut blight is a plant disease caused by the fungus Cryphonectria parasitica (C. parasitica; formerly known as Endothia parasitica). Originally from Asia, the disease has decimated American (Castanea dentata (Marsh.) Borkh.) and European chestnut (C. sativa Mill.) tree populations [1]. The loss of billions of American chestnuts from native landscapes has severely impacted wildlife species dependent upon the mast crops to survive, detrimentally affected the nut and lumber industry economy, and completely reconfigured forests throughout its native range. In Europe, chestnut has fared similarly. Native to Eastern Asia, the fungus has evolved alongside Chinese (C. mollissima) and Japanese ( $C$. crenata) species. Thus, due to genetic evolution, high levels of resistance have been found in Asian chestnut species [2-4]. C. parasitica infection is characterized by the formation of necrotic lesions (cankers) on the bark and branches of susceptible trees [5,6]. These cankers are also a significant source of oxalic acid, a chemical toxic to chestnut tissues [7]. Studies in European chestnut indicated that the greatest concentration of cankers was most often found on larger (>30 cm DBH), more mature trees $[8,9]$.

An extremely persistent fungal pathogen found primarily on chestnut trees, C. parasitica will also colonize other tree species such as sessile oak (Quercus petraea) [10], pedunculate oak (Q. robur), and common beech (Fagus sylvatica) to some degree [11]. Susceptible American chestnut trees typically exhibit $100 \%$ mortality rates after infection, although the longevity of the tree afterwards is variable [12-14].

A hallmark of a virulent C. parasitica infection is the formation of sunken cankers caused by the accelerated deterioration and death of tissue beneath the bark [15]. An enlarged, 
primarily superficial canker often forms in trees infected with the hypovirus [2,16-18]. While these morphologies are often seen with the respective infection types, researchers have not indicated conclusively that these generalizations are reliable [19].

Several other Cryphonectria spp. can be found on chestnut (i.e., Cryphonectria japonica, Cryphonectria radicalis, Cryphonectria naterciae); however, these strains fail to cause cankers [20]. The majority of efforts to curtail the spread of $C$. parasitica such as burning, herbicide application, felling, and quarantine [21-24] have failed. Much greater success for the control of chestnut blight has come from the use of mycoviruses, viruses capable of replication within fungal cells, as biological control agents [25-27].

Hypovirulence is achieved when a cytoplasmic determinant within a mycovirus capable of infecting C. parasitica and leading to its attenuation is transmitted to a virulent strain. Mycoviruses use hyphae fusion (i.e., anastomosis) to transfer the virus from an infected strain to the virulent $C$. parasitica strain aided by the CHV-1 hypovirus (Cryphonectria hypovirus 1) [28]. The single stranded RNA (ssRNA) CHV-1 hypovirus can be identified by a trademark reduction in C. parasitica pigmentation, limited sporulation, and a negation of female fungus fecundity [29]. Three additional hypovirulent mycoviruses have been identified from Cryphonectria spp., but all have varied effects on the persistence of lethality in $C$. parasitica [30]. CHV-2 severely limits $C$. parasitica fertility, proper growth and development, and virulence [31], while CHV-3 primarily contributes to the diminished virulence of the fungus [32]. The least obvious of the CHV hypoviruses is CHV-4 as it has little effect on $C$. parasitica overall.

The C. parasitica fungus shows little genetic diversity, specifically within vegetative compatibility (vc) types, in studies from Azerbaijan [33], Spain [34], and Romania [35,36], but studies in Croatia and Slovenia report considerable diversity [37]. Increased diversity within vc types is often considered a negative outcome of sexual reproduction; however, these data may be misleading when natural populations rather than laboratory populations are examined [38-44].

The incorporation of hypovirulence with the CHV-1 hypovirus was most effective in efforts to save European chestnut when populations steeply declined throughout Europe $[45,46]$. Efforts to contain the spread of C. parasitica infection in urban areas where individual trees were infected have been extremely successful [22,23], while large-scale eradication efforts at the stand level have had limited success [47].

In other European chestnut studies, it was noted that cankers healed on a number of trees because of naturally occurring hypovirulence. However, the conversion from lethal to healing cankers appeared to be variable in studies of inoculation by Diamandis et al. [48], though percentages varied considerably. Celiker et al. [47] indicated a prevalence of healed cankers on shaded western slopes, and also proposed that ants and snails may have contributed to the observed spread of hypovirulence found in areas where no hypovirulent strains were previously inoculated. Observed over time, assisted inoculation proved less effective than natural hypovirulence as many trees eventually succumbed to blight, despite the presence of healed or healing cankers [47]. Systematic inoculation to propagate hypovirulence may be an appropriate standard practice to slow chestnut blight infection [48]; however, a lengthy time period, often between 20 and 50 years, exists between initial chestnut blight observation and the subsequent appearance of healed cankers [49]. Thus, regions with little evidence of a natural hypovirus may be coming to the end of the lag period and could soon reveal presence of a natural hypovirus. Perpetuation of $C$. parasitica and hypovirus spread has also shown to be influenced by the presence of other fungal species [50] as those groups may effectively hinder hypovirus spread. Therefore, C. parasitica spread and rapid canker expansion may be aided by the prevalence of competitive fungi inhibitors of the hypovirus.

Ten years ago, it was thought that the treatment of chestnut blight cankers with an inoculation of a transgenic hypovirus would initiate the spread of the treatment to other nearby trees, as transgenic hypovirulent strains of $C$. parasitica can transmit hypoviruses with $100 \%$ efficiency to ascospore progeny through asexual spores [51]. Unlike natural strains, 
transgenic versions possess full-length infectious cDNA copies of virulence-attenuating hypoviruses that have been chromosomally integrated [51]. Double et al. [51] used inoculum reservoirs and direct application of the hypovirus at different plots over the course of a decade to measure the natural and assisted spread of chestnut blight treatment. The Double et al. [51] data also indicated that punch-initiated infections led to the greatest mortality rates; however, the overall health of the trees before the study may have led to those results. Outcrossing with naturally occurring strains can perpetuate the hypovirus, although dissemination rates varied depending upon fungal isolate type [52], location [53], treatment method [51], and vegetative compatibility [53-57]. Regardless of the undulating success of researchers, work by Zlatanov et al. [24] indicated spread of chestnut blight has slowed in Europe as our understanding and implementation of hypovirulence studies has increased. Hypovirulence has only marginally controlled chestnut blight in several U.S. locations (Connecticut, CHV1 and CHV3; Michigan, CHV3; Virginia, CHV1; and West Virginia, CHV3) but has failed in others (Wisconsin, CHV1, CHV3) [3]. Hypovirus application in the U.S. thus far is a concentrated effort to keep individual American chestnut trees alive for use in breeding but is not recommended for blanket protection because of poor natural dissemination [3]. Recent work by Ko et al. [58] on C. parasitica DNA methylation and by Demené et al. [59] on genomic sequencing and chromosomal rearrangement within the fungus may provide clues to slowing the infection and spread of the fungus within the United States.

Determination of a particular treatment for chestnut blight relies primarily on the downstream uses for the trees. Owners interested in nut production are assured a valuable harvest, while those dependent upon market prices for chestnut products have less incentive to continue chestnut plantation treatment and management [60]. The influx of chestnut blight has limited market demand for chestnut products. Thus, abandonment, or substitution for exotic species rather than implementation of expensive chestnut blight prevention measures, may become commonplace for timber plantations unless the chestnut wood products market can be revived [60]. Olivia et al. [60] suggested that the lack of economical disease and pest treatments for other low-value timber species may prevent landowners from attempting to save those species on the landscape as well. The main objectives of this study were to observe the spread of a natural C. parasitica infection within two size- and age-matched $C$. dentata stands, isolate the $C$. parasitica fungus and the potential hypovirus from Site B, attempt to convert virulent strains into hypovirulent ones by hyphal fusion, and identify a cause for the differing results observed between Site B and Site C.

\section{Materials and Methods}

\subsection{Site Information}

Two privately owned size- and age-matched orchards (each $\leq 50$ ha) were used in this work. Orchard one (Site B) was located in Fulton Co., IN, USA, while Orchard two (Site C) was located $32 \mathrm{~km}$ away in Marshall Co., IN, USA (Figure 1). Both orchards were planted in 2000 using the same batch of pure American chestnut seedlings (Castanea dentata) from the American Chestnut Cooperative (https://www.accf-online.org/; accessed on 14 April 2021) and occupy similar well-drained silty loam soils. Seedlings were identified as 'McDaniels' half-sibs from an open pollinated grafted orchard. 


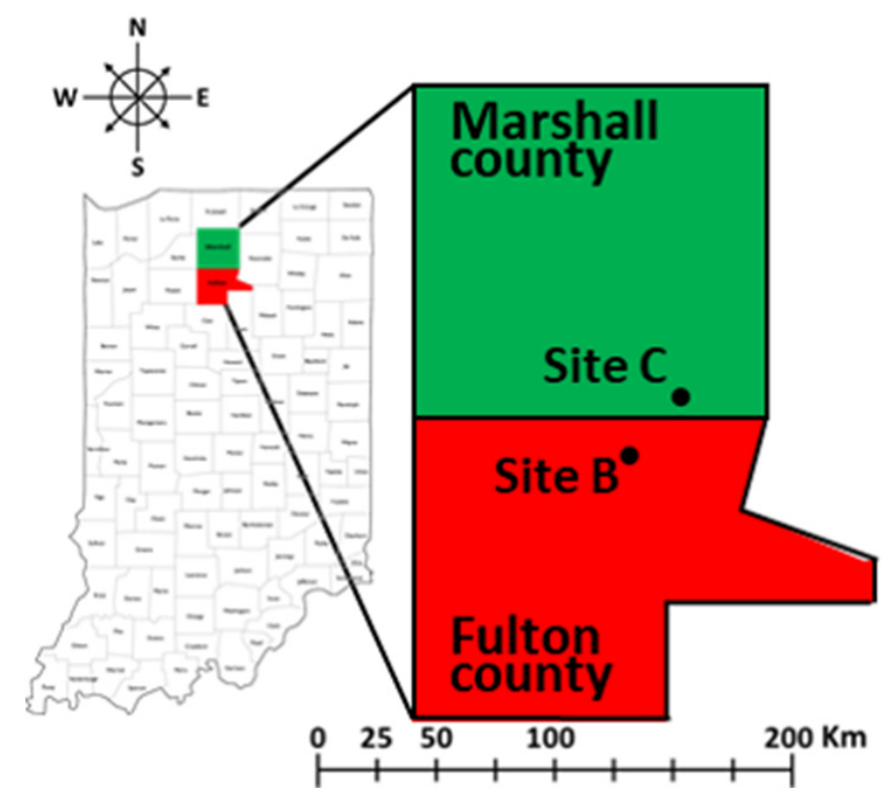

Figure 1. Site locations. Illustration of the relative distance between the Site B and Site C study sites.

\subsection{Growth Measurements and Blight Evaluation}

Tree growth was determined using Haglöf Mantax Blue calipers (Haglof Inc., Madison, MS, USA) specifically designed for the measurement of DBH in 2011 and 2017. Blight evaluations are subjective and were conducted by the same person to limit variability. Ratings ranged from one to three where $1=$ low (few cankers present with no large cankers), $2=$ moderate (a few or several large cankers present in a general area), or $3=$ severe (obvious cracks and numerous large cankers present throughout the tree) disease infection, based on canker number and size.

\subsection{Cryphonectria parasitica Isolates}

Three confirmed pure isolates of C. parasitica ('SG' strain) [61] were provided by The American Chestnut Foundation (TACF, www.acf.org; accessed on 14 April 2021).

\subsection{Isolate Growth and Attempted Conversion}

Bark samples collected from branch crotches and putatively healed cankers on the trunk and scaffold limbs $2 \mathrm{ft}$ to $12 \mathrm{ft}$ from the base of the tree in 2017 were cultured in half-strength potato dextrose media before being plated on PDA (Figure 2). Isolates were grown on half-strength PDA plates in alternating $12 \mathrm{~h}$ dark/light cycles at $25^{\circ} \mathrm{C}$ for $7 \mathrm{~d}$ according to protocols by [62]. Resultant culture mycelium were orange, yellow, or white and were consistent with C. parasitica isolates. Orange and yellow cultures grew quickly and displayed abundant pycnidia $[9,63]$. White mycelium grew slower, showed no pigmentation, and displayed few or no pycnidia or evidence of sporulation as reported for hypovirulent strains $[9,63]$. Attempted transmission, where compatible virulent strains were converted to hypovirulence, involved plating potentially virulent isolates (orange) with those potentially expressing hypovirus (white) together on a single plate in the dark at $25{ }^{\circ} \mathrm{C}$ for $14 \mathrm{~d}$. Samples of both the orange and white isolates were then submitted for genomic sequencing analysis to the Purdue University Plant and Pest Diagnostic Lab (PPDL; https://ag.purdue.edu/btny/ppdl/Pages/default.aspx; accessed on 14 April 2021). The PPDL sequenced each submitted sample using internal transcribed spacer 1 (ITS1) and 4 (ITS4). Sequences were then subjected to BLAST (NCBI, https:/ /blast.ncbi.nlm.nih.gov/ Blast.cgi; accessed on 14 April 2021), where a match was proclaimed $98-100 \%$ identity to C. parasitica. 


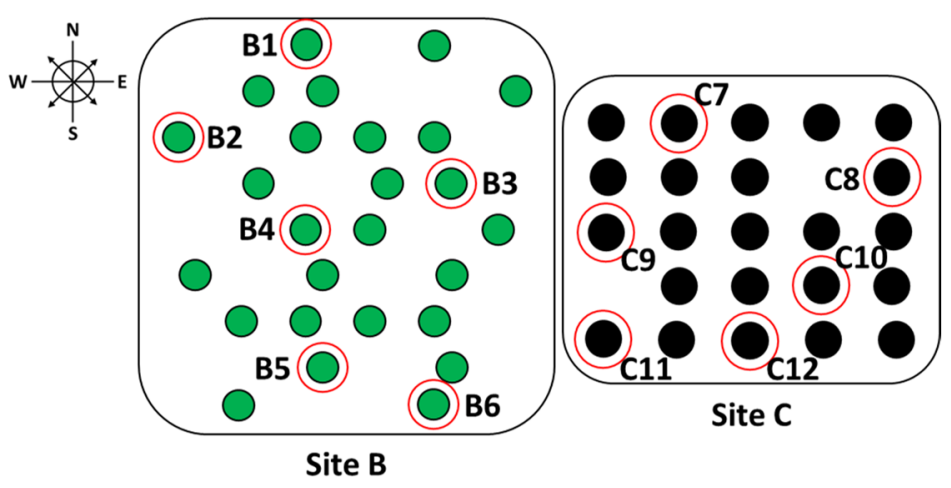

Figure 2. Sampling. A total of twelve samples were taken from Site B and Site C in 2017 after it was noted that Site B was healthy again and Site C had not recovered.

\section{Results}

Blight evaluations conducted in 2011 noted that 26 of 50 seedlings survived in Site B, while 23 of 25 seedlings survived in Site C (Figure 3). The dramatic loss in Site B was attributed to flooding rather than disease. We observed numerous buck rubs and significant browse damage at both sites consistent with an overwhelming ungulate presence. Thus, numerous entry points were available for $C p$ infection.
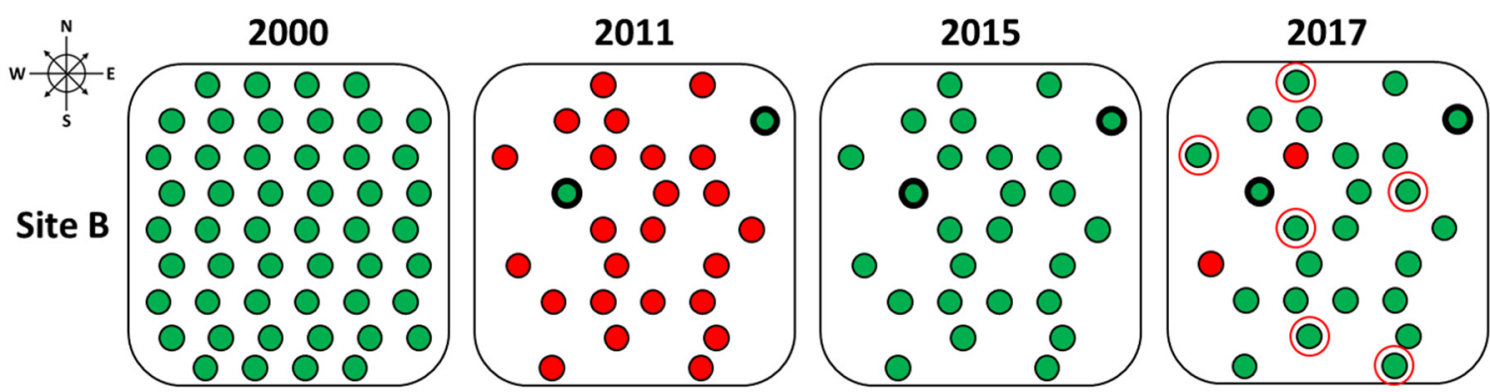

Healthy - Cp positive
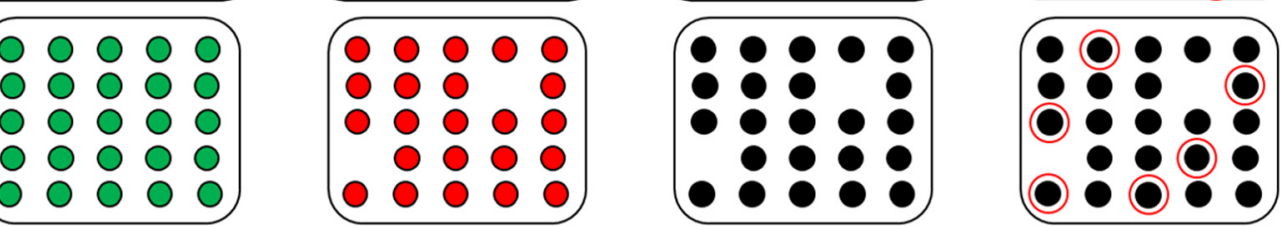

Died back

Sampled

Figure 3. Disease progression. Representative depiction of disease presence at the Site B and Site C sites across several years. Tree mortality from causes unrelated to blight are excluded from 2011 onward.

At the conclusion of the 11th year (2011), 92\% of trees at Site B and $100 \%$ of trees at Site $C$ were diseased (Table 1). Canker ratings on the severity of disease for each of the trees within Site B (1.6) and Site C (1.5) were similar, with few trees displaying canker ratings above moderately affected (rating 2). Further, after repeated visits, these data showed the disease was initiated about 8 years prior and had progressed to a mild to moderate state for all trees. Measurements taken in 2011 at each site indicated growth was initially more rapid at Site $C$, with an average annual growth rate of $0.47 \mathrm{in} / \mathrm{yr}$ and $\mathrm{DBH}$ averaging $5.1 \mathrm{in}$. Trees at Site B demonstrated average annual growth rates of $0.29 \mathrm{in} / \mathrm{yr}$ and DBH values of 3.2 in (Table 1). Diseased trees at Site B began to recover in 2012 and showed no new, active cankers in 2013. Site B exhibited no new canker development from 2014 to 2017, and those trees that died back as a result of disease all resprouted with numerous 4 to 7 year old healthy stems. Disease progression was markedly more pronounced at Site C, with a steady increase in disease severity until all 23 trees and prospective resprouting stems died by the end of 2015 (Figure 3). A visit to the site in Fall 2020 showed several trees at Site C had resprouted. 
Table 1. Visual characteristics. Measurements and canker ratings from 2011.

\begin{tabular}{ccccc}
\hline Orchard & $\begin{array}{c}\text { Avg. Height } \\
\text { (ft) }\end{array}$ & $\begin{array}{c}\text { Avg. DBH } \\
\text { (in) }\end{array}$ & Avg. Canker Rating (1-3) & $\begin{array}{c}\text { Avg. Disease } \\
\text { Progress (\%) }\end{array}$ \\
\hline Site B & 17.5 & 3.2 & 1.6 & 92 \\
Site C & 22.1 & 5.1 & 1.5 & 100 \\
\hline
\end{tabular}

Nine potential $C p$ isolates were recovered from Site $C$ but none from Site B. The 21 initial fungal samples recovered from Site B were Pestalotia spp. and other saprophytic fungi (Table 2). Attempts to assay biocontrol with microbes derived from Site B were ineffective and isolates from Site B and Site $C$ were inconclusive for hypovirulence. A total of 310 isolates were obtained from 19 individual trees (13 Site B, 6 Site C) (Tables 2 and 3). Upon plating, it was observed that isolates from Site B often appeared to be fluffy and white, while those from Site $C$ were most often of an orange hue (Figure 4). Further investigation indicated nine isolates from Site $C$ and two from Site B appeared positive for Cp (Tables 2 and 3).

Table 2. Initial samples and isolates from 2017 after $2 \mathrm{~d}$ incubation on PDA media.

\begin{tabular}{|c|c|c|c|c|c|}
\hline Orchard & Tree & No. Bark Samples (6 mm) & No. Fungal Isolates & Isolates per Sample (\%) & Confirmed $C p$ Isolates \\
\hline Site B & B1 & 9 & 6 & 67 & 0 \\
\hline Site B & B2 & 10 & 2 & 20 & 0 \\
\hline Site B & B3 & 9 & 1 & 11 & 0 \\
\hline Site B & B4 & 12 & 7 & 58 & 0 \\
\hline Site B & B5 & 14 & 1 & 7 & 0 \\
\hline Site B & B6 & 12 & 4 & 33 & 0 \\
\hline Site C & C7 & 8 & 3 & 38 & 2 \\
\hline Site C & $\mathrm{C} 8$ & 5 & 2 & 40 & 2 \\
\hline Site C & C9 & 7 & 4 & 57 & 0 \\
\hline Site C & $\mathrm{C} 10$ & 6 & 3 & 50 & 1 \\
\hline Site C & $\mathrm{C} 11$ & 7 & 4 & 57 & 3 \\
\hline Site C & C12 & 8 & 2 & 25 & 1 \\
\hline Totals & & 107 & 39 & $39 *$ & 9 \\
\hline
\end{tabular}

${ }^{*}$ Average percentage of isolates per sample.

Table 3. Secondary samples and isolates from 2017. Two days after plating on PDA.

\begin{tabular}{|c|c|c|c|c|c|}
\hline Orchard & Tree & No. Bark Samples (6 mm) & $\begin{array}{l}\text { No. Fungal } \\
\text { Isolates }\end{array}$ & Isolates per Sample (\%) & No. Putative $C p \mathrm{HV}$ Isolates \\
\hline Site B & B2 & 14 & 6 & 43 & 0 \\
\hline Site B & B5 & 12 & 3 & 25 & 0 \\
\hline Site B & B6 & 8 & 2 & 25 & 0 \\
\hline Site B & B7-y $\ddagger$ & 10 & 4 & 40 & 0 \\
\hline Site B & $\mathrm{B} 7-\mathrm{O}^{+}$ & 18 & 4 & 22 & 0 \\
\hline Site B & B8-1 & 8 & 2 & 25 & 0 \\
\hline Site B & B8-2 & 29 & 11 & 38 & 0 \\
\hline Site B & B9-1 & 13 & 2 & 15 & 0 \\
\hline Site B & B9-2 & 5 & 1 & 20 & 0 \\
\hline Site B & B10 & 11 & 3 & 27 & 0 \\
\hline Site B & B11 & 9 & 1 & 11 & 0 \\
\hline Site B & B12 & 13 & 5 & 38 & 0 \\
\hline Site B & B12-Cp & 19 & 6 & 32 & 1 \\
\hline Site B & B13 & 13 & 5 & 38 & 0 \\
\hline Site B & $\mathrm{B} 13-\mathrm{C} p$ & 21 & 5 & 24 & 1 \\
\hline Totals & & 203 & 60 & $28 *$ & 2 \\
\hline
\end{tabular}

${ }^{*}$ Average, ${ }^{\ddagger}$, (yellow color), ${ }^{\dagger}$, (orange color). 

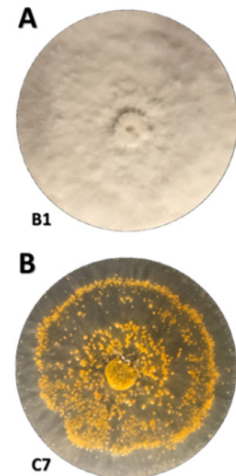
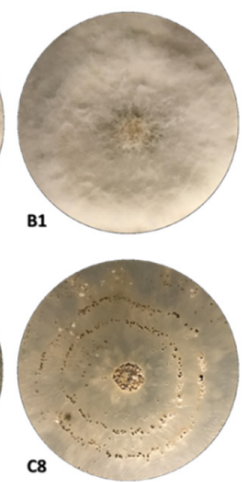
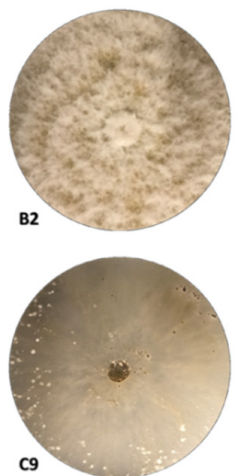
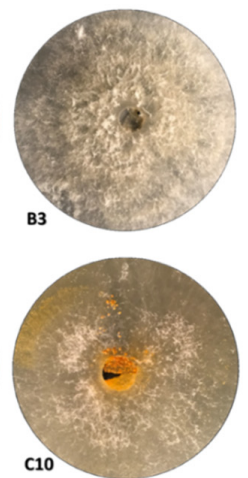
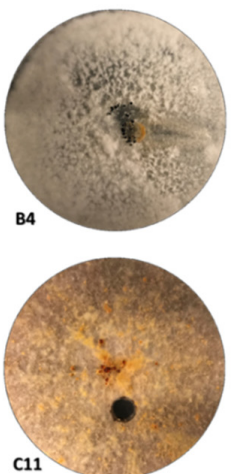

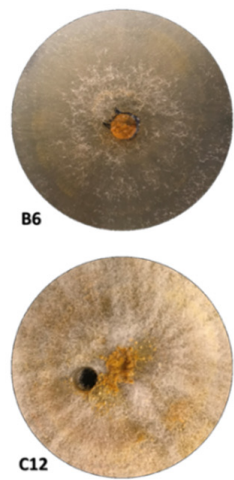

C12

Figure 4. Isolate growth. Of the different isolates from Site B (A), the primary color observed was white, a color usually attributed to hypovirulent colonies. The six isolates from Site C (B) were primarily orange, a color typically indicative of virulent isolates. The punch holes observed were used to initiate a new plate of growth and were made before the previous plates became confluent.

Colonies from both Site B and Site $C$ were plated against pure $C p$ strains in an attempt to induce conversions (Figure 5). Each plated pair resulted in incompatible plate reactions; thus, we were unable to confirm conversion from our plated cultures. The potential positive isolates from Site B (B12, B13) had an orange color that later became white before sequencing confirmed they were not positive for $C p$ (Figure 6). The Purdue University Plant and Pest Diagnostic Lab (PPDL; https: / / ag.purdue.edu/btny/ppdl/Pages/default.aspx; accessed on 14 April 2021) confirmed the orange Site $C$ isolates were $C p$ and the Site B isolates were other fungal species (Supplemental Table S1. Sequencing results using ITS primers for evaluation of potential Cryphonectria parasitica isolates.).
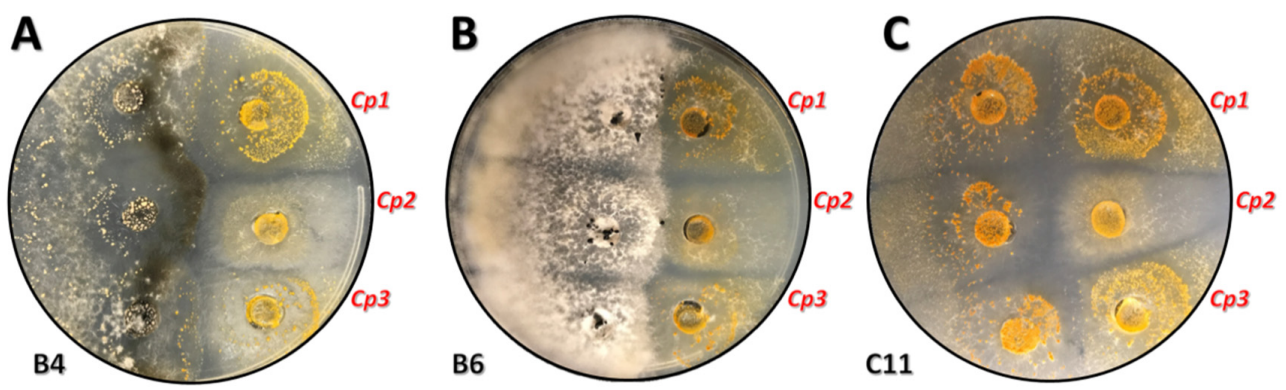

Figure 5. Conversion attempts. Isolates from Site B $(\mathbf{A}, \mathbf{B})$ and Site $C(\mathbf{C})$ were plated with pure strains of $C p 1,2$, and 3 to induce conversion. Clear barrage zones appeared between each colony, an indication of both vegetative incompatibility and a lack of transmission.

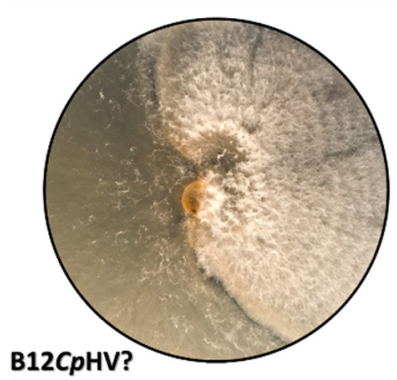

Figure 6. Putative $\mathrm{C} p \mathrm{HV}$ from secondary sampling. Two Site B isolates (B12C $p \mathrm{HV}$ ?, B13C $p^{*}$ ) began with an orange hue before transitioning to white and were considered putatively positive $C \mathrm{HV}$ isolates. ${ }^{*} \mathrm{~B} 13 \mathrm{C} p$ transition not captured. 


\section{Discussion}

Past work has shown that there are a number of interacting variables involved in the chestnut response to C. parasitica and, while populations in Europe seem to be doing slightly better in response to hypoviruses, stresses such as drought and insect pests (i.e., the Asian chestnut gall wasp (Dryocosmus kuriphilus Yasumatsu) [64]) represent another barrier to the restoration of this majestic species. In addition, continuous observation of the diversity of vc types and hypovirus ranges within existing chestnut populations is necessary to track progress. Advances in research regarding hypovirulence have slowed the spread of chestnut blight in Europe [24]. Natural hypovirulence may be essential for the effective biological control of the chestnut blight disease [41]. Unfortunately, recombination events could lead to increased vc type diversity, thus potentially interfering with natural controls [23]. In addition, research data also noted that success is more apt to occur in intensely managed stands rather than abandoned ones irrespective of vc diversity [65].

In the United States, evaluations of American chestnut for potential restoration have shown its distribution is significantly influenced by soil parameters and site topography, with $\mathrm{pH}$ and slope angle serving as primary predictors [66]. Additional parameters such as soil composition and precipitation during the growing season [66] and relatedness of tree species [54] also play significant roles. It is thought that chestnut distribution on the landscape varies with genotype as studies have noted pure American chestnut and hybrid varieties require differing environments for optimal growth [66,67].

Because CHV-1 subtype can vary, correct identification of the strain you have isolated is paramount. Hoegger et al. [68] reported that CHV-1 subtype-I can be established in native $C$. parasitica populations but is less effective than $\mathrm{CHV}-1$ subtypes $\mathrm{F} 1$ and F2. CHV-1 subtypes F1 and F2 dramatically decrease the virility of $C$. parasitica when used on isolated urban trees or individual cankers; however, dissemination efforts have been primarily ineffectual [69]. Studies of natural chestnut populations stated CHV-1 subtype-I slowed canker development by greater than $80 \%$ and, on this basis, is being considered for use as a biological control agent [49]. Ježić et al. [68] noted that CHV-1-infected wild chestnut trees were able to recover after exposure; however, grafted chestnut failed to form healed cankers and later succumbed to C. parasitica infection.

Future efforts to improve biological control success require in-depth details regarding the relationship between C. parasitica and various hypovirus strains capable of attenuation. At this point, more research is needed to illuminate this complex relationship. On the other hand, sexual reproduction and the increase of vc type diversity by recombination could obstruct natural biological control. Since sustainable biological control of chestnut blight requires a comprehensive knowledge of the dynamics of the Cryphonectria-hypovirus interaction, additional population studies of the fungus and the hypovirus will be necessary. Alternative means used to investigate resistance levels have ranged from backcrossing [70] and interspecific crosses [43] to the generation of transgenics [71], genotyping [60] and genome editing [72]. New research published by Meyer et al. [73] noted C. parasitica and the $\mathrm{C} p \mathrm{HV}$ can survive on the bark of fresh dead chestnut for over two years. This suggests fresh dead wood could be used as a vector for transmission of both agents in the forest, recommendations for the removal of fresh dead chestnut from the forest may be detrimental if $\mathrm{C} p \mathrm{HV}$ is present [73], and that time is a critical factor [74].

A clear explanation as to the sudden recovery of Site B when a similar site, Site C, was completely decimated remains a topic for further discussion. Our hypotheses led us to believe that $\mathrm{CpHV}$ was present at Site B. Despite our best efforts to isolate and verify this, our samples did not confirm the presence of $\mathrm{C} p \mathrm{HV}$ after several rounds of sample collection and subsequent sequencing. If we can obtain a confirmed $C p$ isolate from Site B, we aim to culture the $\mathrm{CpHV}$ strain and offer it as an alternative biocontrol method in Indiana. Other theories to explain the phenomena observed at Site B involve an unintended benefit from the flooding event or from the presence of an unknown environmental factor in the area encompassing Site B. We have continued to focus on genotyping the nine $C p$ isolates recovered from Site $C$ for later reports on the genetic diversity within native $C p$ populations. 
Additional efforts will pursue the identification and isolation of $C p$ isolates at Site B from younger branches at a range of positions within the canopy. Scaling up field sterilization and removal of outer bark will be carried out to limit saprophyte contamination. Intensive sampling from the two trees in Site B unaffected at any point with chestnut blight will be performed in conjunction with the continued monitoring and measurement of the Site B study site.

Previous research by Bissegger et al. [75] noted strain conversion was successful if previously orange strains underwent a color change and exhibited characteristics similar to those of white cultures. This observation was further confirmed by later researchers [45,69,76,77]. However, we recognized, as did Celiker et al. [47], the need to verify the presence of hypovirulence in white isolates, as color alone cannot confirm the presence of the hypovirus. Cultures were thought to be virus-infected if their morphology was akin to that of confirmed CHV-1 hypoviruses. In our study, several orange cultures appeared to develop white characteristics, but further evaluation by experts failed to confirm presence of a hypovirus. In addition, incompatible plate reactions were observed between ascospore colonies plated together during conversion testing similar to those of Double et al. [20] and Rigling and Prospero [51].

\section{Conclusions}

Our goal was to recover $C p$ isolates at both orchards and then to identify hypovirulent isolates of $C p(C p H V)$. Without confirmation via an isolate collected at Site B, we must refrain from concluding that $\mathrm{C} p \mathrm{HV}$ is responsible for the dramatic difference in survival at these two sites. Ultimately, we aimed to identify and culture a native Indiana $\mathrm{CpHV}$ strain as a biocontrol for chestnut blight in Indiana. This would allow for progression of American chestnut restoration efforts in its native range and throughout the region.

Supplementary Materials: The following are available online at https://www.mdpi.com/article/ 10.3390/f12060794/s1, Table S1: Sequencing results using ITS primers for evaluation of potential Cryphonectria parasitica isolates.

Author Contributions: Conceptualization, J.R.M., A.E.; methodology, J.R.M., A.E., S.S.L.; data analysis, J.R.M., A.E., S.S.L.; data collection, A.E.; writing, S.S.L.; review, J.R.M., A.E., S.S.L.; visualization, S.S.L.; All authors have read and agreed to the published version of the manuscript.

Funding: This research was funded by the USDA Forest Service Northern Research Station (www. htirc.org; accessed on 14 April 2021), the Fred M. van Eck Foundation, and the American Chestnut Foundation (www.acf.org; accessed on 14 April 2021).

Data Availability Statement: Data sharing not applicable.

Acknowledgments: We thank the Indiana Nature Conservancy (IN-TNC) for supporting HTIRC's program for chestnut tree improvement. We thank Tom Creswell of the Purdue PPDL for identifying isolates, Jason Cook from Arbor America Inc., Mark Double from West Virginia University, the Indiana Chapter of the American Chestnut Foundation (IN-TACF), the Forestry \& Natural Resources Department at Purdue University, and the USDA Forest Service, Northern Research Station for their ongoing support. We thank Anna Conrad for her comments and review of a previous version of this work. Mention of a trademark, proprietary product, or vendor does not constitute a guarantee or warranty of the product by the US Department of Agriculture and does not imply its approval to the exclusion of other products or vendors that also may be suitable.

Conflicts of Interest: The authors declare no conflict of interest.

\section{References}

1. Milgroom, M.G.; Wang, K.; Zhou, Y.; Lipari, S.E.; Kaneko, S. Intercontinental population structure of the chestnut blight fungus, Cryphonectria parasitica. Mycologia 1996, 88, 179-190. [CrossRef]

2. Heiniger, U.; Rigling, D. Biological control of chestnut blight in Europe. Annu. Rev. Phytopathol. 1994, 32, 581-599. [CrossRef]

3. Milgroom, M.G.; Cortesi, P. Biological control of chestnut blight with hypovirulence: A critical analysis. Annu. Rev. Phytopathol. 2004, 42, 311-338. [CrossRef] [PubMed] 
4. Rea, G. What is blight resistance? J. Am. Chestnut Found. 2012, 26, 3. Available online: https://www.acf.org/wp-content/ uploads/2016/08/Blight-Resistance.pdf (accessed on 14 April 2021).

5. Anagnostakis, S. Biological control of chestnut blight. Science 1982, 215, 466-471. [CrossRef]

6. Anagnostakis, S. Chestnut blight: The classical problem of an introduced pathogen. Mycologia 1987, 79, 23-27. [CrossRef]

7. Hirsch, R. Blight resistance: It's in the DNA. J. Am. Chestnut Found. 2012, 26, 20-22. Available online: http:/ / www.rebeccahirsch. com/uploads/2/1/5/0/21500942/blight_resistance.pdf (accessed on 14 April 2021).

8. Bragança, H.; Simões, S.; Onofre, N.; Santos, N. Factors influencing the incidence and spread of chestnut blight in northeastern Portugal. J. Plant Pathol. 2009, 91, 53-59. [CrossRef]

9. Murolo, S.; Sciences, E.; Milvia, R. Phenotypic and molecular investigations on hypovirulent Cryphonectria parasitica in Italy. Plant Dis. 2018, 102, 540-545. [CrossRef]

10. Karadžić, D.; Radulović, Z.; Sikora, K.; Stanivuković, Z.; Golubović Ćurguz, V.; Oszako, T.; Milenković, I. Characterisation and pathogenicity of Cryphonectria parasitica on sweet chestnut and sessile oak trees in Serbia. Plant Prot. Sci. 2019, 55, 191-201. [CrossRef]

11. Dennert, F.; Rigling, M.; Meyer, J.B.; Schefer, C.; Augustiny, E.; Prospero, S. Testing the pathogenic potential of Cryphonectria parasitica and related species on three common European. Fagaceae. Front. Glob Chang. 2020, 3, 1-8. [CrossRef]

12. Hepting, G.H. Death of the American chestnut. J. For. Hist. 1974, 18, 61-67. [CrossRef]

13. Schlarbaum, S.E.; Hebard, F.; Spaine, P.C.; Kamalay, J.C. Three American tragedies: Chestnut blight, butternut canker, and Dutch elm disease. In Exotic Pests of Eastern Forests Conference Proceedings, Nashville, TN, USA, 8-10 April 1997; Britton, K.O., Ed.; U.S. Forest Service and Tennessee Exotic Pest Plant Council: Nashville, TN, USA, 1997; pp. 45-54. Available online: https:/ / www.fs.usda.gov/treesearch/pubs/745 (accessed on 14 April 2021).

14. Reynolds, D.L.; Burke, K.L. The effect of growth rate, age, and chestnut blight on American chestnut mortality. Castanea 2011, 76, 129-139. [CrossRef]

15. Davelos, A.L.; Jarosz, A.M. Demography of American chestnut populations: Effects of a pathogen and a hyperparasite. J. Ecol. 2004, 92, 675-685. [CrossRef]

16. Lee, S.H.; Moon, B.J.; Lee, J.K. Characteristics of hypovirulent strains of chestnut blight fungus, Cryphonectria parasitica, isolated in Korea. Mycobiology 2006, 34, 61-66. [CrossRef]

17. Prospero, S.; Rigling, D. Invasion genetics of the chestnut blight fungus Cryphonectria parasitica in Switzerland. Phytopathology 2012, 102, 73-82. [CrossRef]

18. Bryner, S.F.; Prospero, S.; Rigling, D. Dynamics of Cryphonectria hypovirus infection in chestnut blight cankers. Phytopathology 2014, 104, 918-925. [CrossRef] [PubMed]

19. Bryner, S.F.; Sotirovski, K.; Akilli, S.; Risteski, M.; Perlerou, C.; Rigling, D. Informative value of canker morphology on the presence or absence of virus infection in chestnut blight cankers. For. Pathol. 2013, 43, 496-504. [CrossRef]

20. Rigling, D.; Prospero, S. Cryphonectria parasitica, the causal agent of chestnut blight: Invasion history, population biology and disease control. Mol. Plant Pathol. 2018, 19, 7-20. [CrossRef] [PubMed]

21. Seemann, D. Plant health and quarantine regulations of the European Union for Cryphonectria parasitica. For. Snow Landsc. Res. 2001, 76, 402-404. Available online: https://www.dora.lib4ri.ch/wsl/islandora/object/wsl:15416 (accessed on 14 April 2021).

22. Krstin, L.; Rigling, D.; Kraja, M. Chestnut blight fungus in Croatia: Diversity of vegetative compatibility types, mating types and genetic variability of associated Cryphonectria hypovirus 1. Plant Pathol. 2008, 57, 1086-1096. [CrossRef]

23. Krstin, L.; Rigling, D. Diversity of vegetative compatibility types and mating types of Cryphonectria parasitica in Slovenia and occurrence of associated Cryphonectria hypovirus 1. Plant Pathol. 2012, 60, 752-761. [CrossRef]

24. Zlatanov, T.; Velichkov, I.; Georgieva, M.; Hinkov, G.; Zlatanova, M.; Gogusev, G.; Eastaugh, C. Does management improve the state of chestnut (Castanea sativa L.) on Belasitsa Mountain, southwest Bulgaria? IForest 2015, 8, 860-865. [CrossRef]

25. Krstin, L.; Katani, Z.; Ježi, M.; Poljak, I.; Nuskern, L.; Idžojti, M. Biological control of chestnut blight in Croatia: An interaction between host sweet chestnut, its pathogen Cryphonectria parasitica and the biocontrol agent Cryphonectria hypovirus 1. Pest. Manag. Sci. 2016, 73, 582-589. [CrossRef] [PubMed]

26. Prospero, S.; Cleary, M. Effects of Host Variability on the Spread of Invasive Forest Diseases. Forests 2017, 8, 80. [CrossRef]

27. Lovat, C.-A.; Donnelly, D.J. Mechanisms and metabolomics of the host-pathogen interactions between Chestnut (Castanea species) and Chestnut blight (Cryphonectria parasitica). For. Pathol. 2019, 49, e12562. [CrossRef]

28. García-Pedrajas, M.D.; Cañizares, M.C.; Sarmiento-Villamil, J.L.; Jaquat, A.G.; Dambolena, J.S. Mycoviruses in biological control: From basic research to field implementation. Phytopathology 2019, 109, 1828-1839. [CrossRef]

29. Linder-Basso, D.; Dynek, J.N.; Hillman, B.I. Genome analysis of Cryphonectria hypovirus 4, the most common hypovirus species in North America. Virology 2005, 337, 192-203. [CrossRef] [PubMed]

30. Xie, J.; Jiang, D. New insights into mycoviruses and exploration for the biological control of crop fungal iseases. Annu. Rev. Phytopathol. 2014, 52, 45-68. [CrossRef]

31. Hillman, B.I.; Halpern, B.; Brown, M.P. A viral dsRNA element of the chestnut blight fungus with a distinct genetic organization. Virology 1994, 201, 241-250. [CrossRef]

32. Smart, C.D.; Yuan, W.; Foglia, R.; Nuss, D.L.; Fulbright, D.W.; Hillman, B.I. Cryphonectria hypovirus 3, a virus species in the family Hypoviridae with a single open reading frame. Virology 1999, 265, 66-73. [CrossRef] 
33. Aghayeva, D.N.; Rigling, D.; Prospero, S. Low genetic diversity but frequent sexual reproduction of the chestnut blight fungus Cryphonectria parasitica in Azerbaijan. For. Pathol. 2017, 17, e12357. [CrossRef]

34. Robin, C.; Capdevielle, X.; Martin, M.; Traver, C.; Colinas, C. Cryphonectria parasitica vegetative compatibility type analysis of populations in south-western France and northern Spain. Plant Pathol. 2009, 58, 527-535. [CrossRef]

35. Adamčiková, K.; Onrušková, E.; Kádasi-Horáková, M.; Botu, M.; Kobza, M.; Achim, G. Distribution and population structure of the chestnut blight fungus in Romania. Plant Prot. Sci. 2015, 51, 141-149. [CrossRef]

36. Chira, D.; Bolea, V.; Chira, F.; Mantale, C.; Tăut, I.; Şimonca, V.; Diamandis, S. Biological control of Cryphonectria parasitica in Romanian protected sweet chestnut forests. Not. Bot. Horti Agrobot. Cluj Napoca 2017, 45, 632-638. [CrossRef]

37. Krstin, L.; Katani, Z.; Repar, J.; Je, M.; Koba, A.; Mirna, Ć. Genetic diversity of Cryphonectria hypovirus 1, a biocontrol agent of chestnut blight, in Croatia and Slovenia. Microb. Ecol. 2020, 79, 148-163. [CrossRef] [PubMed]

38. Carbone, I.; Liu, Y.; Hillman, B.I.; Milgroom, M.G. Recombination and migration of Cryphonectria hypovirus 1 as inferred from gene genealogies and the coalescent. Genetics 2004, 166, 1611-1629. [CrossRef]

39. Bryner, S.F.; Rigling, D.; Brunner, P.C. Invasion history and demographic pattern of Cryphonectria hypovirus 1 across European populations of the chestnut blight fungus. Ecol. Evol. 2012, 2, 3227-3241. [CrossRef]

40. Risteski, B.M.; Milev, M.; Rigling, D.; Milgroom, M.G.; Bryner, S.F.; Sotirovski, K. Distribution of chestnut blight and diversity of Cryphonectria parasitica in chestnut forests in Bulgaria. Plant Pathol. 2013, 43, 437-443. [CrossRef]

41. Ježić, M.; Mlinarec, J.; Vuković, R.; Katanić, Z.; Krstin, L.; Nuskern, L.; Poljak, I.; Idžojtić, M.; Tkalec, M.; Ćurković-Perica, M. Changes in Cryphonectria parasitica populations affect natural biological control of Chestnut Blight. Ecol. Epidemiol. 2018, 108, 870-877. [CrossRef]

42. Mlinarec, J.; Je, M.; Cosi, J.; Curkovi, M. Multilocus PCR assay reveals high diversity of vegetative compatibility types in populations of Cryphonectria parasitica in Croatia. Plant Pathol. 2018, 67, 741-749. [CrossRef]

43. Rigling, D.; Borst, N.; Cornejo, C.; Supatashvili, A.; Prospero, S. Genetic and phenotypic characterization of Cryphonectria hypovirus 1 from Eurasian Georgia. Viruses 2018, 10, 687. [CrossRef] [PubMed]

44. Risteski, M.; Karin-Kujundžić, V.; Idžojtić, M.; Poljak, I.; Ćurković-Perica, M. Diversity of Cryphonectria parasitica in callused chestnut blight cankers on European and American chestnut. For. Pathol. 2019, 49, 1-8. [CrossRef]

45. Zamora, B.P.; Martín, A.B.; Rigling, D.; Diez, J.J. Diversity of Cryphonectria parasitica in western Spain and identification of hypovirus-infected isolates. For. Pathol. 2012, 42, 412-419. [CrossRef]

46. Kazmierczak, P.; Mccabe, P.; Turina, M.; Jacob-wilk, D.; van Alfen, N.K. The mycovirus CHV1 disrupts secretion of a developmentally regulated protein in Cryphonectria parasitica. J. Virol. 2012, 86, 6067-6074. [CrossRef]

47. Çelİker, N.M.; Kaplan, C.; Onoğur, E.; Çetİnel, B.; Poyraz, D.; Uysal, A. Natural dissemination of hypovirulent Cryphonectria parasitica strain used for biological control of chestnut blight. Turk. J. Agric. For. 2017, 41, 278-284. [CrossRef]

48. Diamandis, B.S.; Perlerou, C.; Tziros, G.T.; Christopoulos, V.; Topalidou, E. Establishment and dissemination of hypovirulent strains of Cryphonectria parasitica in Greece. For. Pathol. 2015, 45, 408-414. [CrossRef]

49. Trapiello, E.; Rigling, D.; González, A.J. Occurrence of hypovirus-infected Cryphonectria parasitica isolates in northern Spain: An encouraging situation for biological control of chestnut blight in Asturian forests. Eur. J. Plant Pathol. 2017, 149, 503-514. [CrossRef]

50. Kolp, M.; Double, M.L.; Fulbright, D.W.; Macdonald, W.L.; Jarosz, A.M. Spatial and temporal dynamics of the fungal community of chestnut blight cankers on American chestnut (Castanea dentata) in Michigan and Wisconsin. Fungal Ecol. 2020, 45, 100925. [CrossRef]

51. Double, M.L.; Nuss, D.L.; Rittenour, W.R.; Holásková, I.; Short, D.P.G.; Kasson, M.T.; MacDonald, W.L. Long-term field study of transgenic hypovirulent strains of Cryphonectria parasitica in a forest setting. For. Pathol. 2017, 47, 1-20. [CrossRef]

52. Zamora, P.; González Casas, A.; Dueñas, M.; San Martin, R.; Diez, J.J. Factors influencing growth, sporulation and virus transfer in Cryphonectria parasitica isolates from Castilla and León (Spain). Eur. J. Plant Path. 2017, 148, 65-73. [CrossRef]

53. Zamora, P.; Martín, A.; Dueñas, M.; Martín, R.S.; Diez, J.J. Cryphonectria parasitica isolates of the same vegetative compatibility type display different rates of transfer of CHV1 hypovirus. For. Pathol. 2015, 143, 767-777. [CrossRef]

54. Akilli, S.; Katircioğlu, Y.Z.; Maden, S. Vegetative compatibility types of Cryphonectria parasitica, causal agent of chestnut blight, in the Black Sea region of Turkey. For. Pathol. 2009, 39, 390-396. [CrossRef]

55. Daldal, M.; Erincik, Ö.; Wall, J.R. Geographical distribution of vegetative compatibility and mating types of Cryphonectria parasitica in İzmir, Manisa and Denizli provinces in western Turkey. For. Pathol. 2018, 48, 1-13. [CrossRef]

56. Cornejo, C.; Rigling, D.; Kupper, Q.; Prospero, S. A multiplexed genotyping assay to determine vegetative incompatibility and mating type in Cryphonectria parasitica. Eur. J. Plant Pathol. 2019, 155, 81-91. [CrossRef]

57. Pérez-Sierra, A.; Romón-Ochoa, P.; Gorton, C.; Lewis, A.; Rees, H.; Van Der Linde, S.; Webber, J. High vegetative compatibility diversity of Cryphonectria parasitica infecting sweet chestnut (Castanea sativa) in Britain indicates multiple pathogen introductions. Plant Pathol. 2019, 68, 727-737. [CrossRef]

58. Ko, Y.H.; So, K.K.; Chun, J.; Kim, D.H. Distinct roles of two DNA methyltransferases from Cryphonectria parasitica in fungal virulence, responses to hypovirus infection, and viral clearance. mBio 2021, 12, e02890-20. [CrossRef] [PubMed]

59. Demené, A.; Laurent, B.; Cros-Arteil, S.; Boury, C.; Dutech, C. Chromosomal rearrangements but no change of genes and transposable elements repertoires in an invasive forest-pathogenic fungus. bioRxiv 2021, 3, e434572. [CrossRef] 
60. Oliva, J.; Castaño, C.; Baulenas, E.; Domínguez, G.; González-Olabarria, J.R.; Oliach, D. The impact of the socioeconomic environment on the implementation of control measures against an invasive forest pathogen. For. Ecol. Manag. 2016, 380, 118-127. [CrossRef]

61. McKechnie, T.S. Some resistance genes against Cryphonectria parasitica may be strain-specific. In Proceedings of the 29th Southern Forest Tree Improvement Conference. Tree Improvement in North America: Past, Present, and Future, WFGA/SFTIC Joint Meeting, Galveston, TX, USA, 19-22 June 2007; p. 96. Available online: https://rngr.net/publications/tree-improvementproceedings/sftic/2007 (Accessed on April 14, 2021).

62. Sun, Q.; Choi, G.H.; Nuss, D.L. Hypovirus-responsive transcription factor gene pro1 of the chestnut blight fungus Cryphonectria parasitica is required for female fertility, asexual spore development, and stable maintenance of hypovirus Infection. Eukaryot. Cell 2009, 8, 262-270. [CrossRef]

63. Puia, C.E.; Grigorescu, A.; Miclea, R.V. The morphology and the biological control of Cryphonectria parasitica. Bull. UASVM Agric. 2012, 69, 353-355. Available online: http:/ / www.researchgate.net/publication/268075980 (Accessed on April 14, 2021).

64. Ugolini, F.; Massetti, L.; Pedrazzoli, F.; Tognetti, R.; Vecchione, A.; Zulini, L.; Maresi, G. Ecophysiological responses and vulnerability to other pathologies in European chestnut coppices, heavily infested by the Asian chestnut gall wasp. For. Ecol. Manag. 2014, 314, 38-49. [CrossRef]

65. González-Varela, G.; González, A.J.; Milgroom, M.G. Clonal population structure and introductions of the chestnut blight fungus, Cryphonectria parasitica, in Asturias, northern Spain. Eur. J. Plant Pathol. 2011, 131, 67-79. [CrossRef]

66. Tulowiecki, S.J. Modeling the historical distribution of American chestnut (Castanea dentata) for potential restoration in western New York State, US. For. Ecol. Manag. 2020, 462, e118003. [CrossRef]

67. Griscom, H.; Griscom, B. Evaluating the ecological niche of American chestnut for optimal hybrid seedling reintroduction sites in the Appalachian ridge and valley province. New For. 2012, 43, 441-455. [CrossRef]

68. Hoegger, P.J.; Heiniger, U.; Holdenrieder, O.; Rigling, D. Differential transfer and dissemination of hypovirus and nuclear and mitochondrial genomes of a hypovirus-infected Cryphonectria parasitica strain after introduction into a natural population. Appl. Environ. Microb. 2003, 69, 3767-3771. [CrossRef] [PubMed]

69. Ježić, M.; Krstin, L.; Poljak, I.; Liber, Z.; Idžojtić, M.; Jelić, M.; Meštović, J.; Zebec, M.; Ćurković-Perica, M. Castanea sativa: Genotype-dependent recovery from chestnut blight. Tree Genet. Genomes 2014, 10, 101-110. [CrossRef]

70. Bauman, J.M.; Howes, C.; Brian, K. Growth performance and chestnut blight incidence (Cryphonectria parasitica) of backcrossed chestnut seedlings in surface mine restoration. New For. 2014, 45, 813-828. [CrossRef]

71. Newhouse, A.E.; Polin-mcguigan, L.D.; Baier, K.A.; Valletta, K.E.R.; Rottmann, W.H.; Tschaplinski, T.J.; Maynard, C.; Powell, W.A. Plant science transgenic American chestnuts show enhanced blight resistance and transmit the trait to T1 progeny. Plant Sci. 2014, 228, 88-97. [CrossRef]

72. Stauder, C.M.; Nuss, D.L.; Zhang, D.; Double, M.L.; Macdonald, W.L.; Metheny, A.M.; Kasson, M.T. Enhanced hypovirus transmission by engineered super donor strains of the chestnut blight fungus, Cryphonectria parasitica, into a natural population of strains exhibiting diverse vegetative compatibility genotypes. Virology 2019, 528, 1-6. [CrossRef]

73. Meyer, J.; Chalmandrier, L.; Fässler, F.; Schefer, C.; Rigling, D.; Prospero, S. Role of fresh dead wood in the epidemiology and the biological control of the chestnut blight fungus. Plant Dis. 2019, 103, 430-438. [CrossRef]

74. Double, M.L.; Jarosz, A.M.; Fulbright, D.W.; Baines, A.D.; Macdonald, W.L. Evaluation of two decades of Cryphonectria parasitica hypovirus introduction in an American chestnut stand in Wisconsin. Phytopathology 2018, 108, 702-710. [CrossRef] [PubMed]

75. Bissegger, M.; Rigling, D.; Heiniger, U. Population Structure and Disease Development of Cryphonectria parasitica in European Chestnut Forests in the Presence of Natural Hypovirulence. Phytopathology 1997, 87, 50-59. [CrossRef] [PubMed]

76. Peters, B.F.S.; Holweg, C.L.; Rigling, D.; Metzler, B. Chestnut blight in south-western Germany: Multiple introductions of Cryphonectria parasitica and slow hypovirus spread. For. Pathol. 2012, 42, 397-404. [CrossRef]

77. Akilli, S.; Ulbaş Serçe, C.; Zekai Katircioğlu, Y.; Maden, S.; Rigling, D. Characterization of hypovirulent isolates of the chestnut blight fungus, Cryphonectria parasitica from the Marmara and Black Sea regions of Turkey. Eur. J. Plant Pathol. 2013, 135, 323-334. [CrossRef] 